\title{
Heme oxygenase-1 reverses HIV-1 Tat activity: prospects for AIDS prevention
}

\author{
ME Cueno ${ }^{*}, \mathrm{~K}$ Imai, K Ochiai \\ From AIDS Vaccine 2012 \\ Boston, MA, USA. 9-12 September 2012
}

\section{Background}

Heme oxygenase-1 (HO-1) is a HEME regulator and plays a role in ameliorating HIV-1 infection. In particular, HO-1 inhibits Tat-dependent activation of HIV-1 LTR promoter inhibiting viral gene expression. This suggests that increasing HO-1 activity in HIV-infected cells can reverse Tat action which may contribute to AIDS prevention. However, the correlation between HO-1 and HIV-1 Tat has not been fully elucidated. In order to fully understand how increasing HO- 1 activity reverses Tat action and result into the prevention of HIV infection, the mechanism behind the correlation between HIV-1 Tat and HO-1 should first be established.

\section{Methods}

Throughout the study we made use of Jurkat $\mathrm{T}$ cells (control) and Jurkat-Tat T cells. Whole cell extracts were obtained and mitochondrial extracts were isolated separately. HO-1, HEME, superoxide dismutase (SOD), catalase and hydrogen peroxide (H2O2) levels were measured using commercially available assays. Immunoassays confirmed both the presence of Tat and NADPH oxidase activity via the HEME-activated gp91phox.

\section{Results}

We found that in Tat-expressing cells, $\mathrm{HO}-1$ and SOD amounts were decreased, HEME and $\mathrm{H} 2 \mathrm{O} 2$ levels were increased and catalase concentration was unchanged. In addition, we observed an accumulation of gp91phox and $\mathrm{H} 2 \mathrm{O} 2$ amounts. We suspect that Tat activity in Jurkat $\mathrm{T}$ cells lead to the following sequence of events: (1) decrease in HO-1 and SOD activities; (2) low SOD amounts leaves catalase amounts unchanged; (3) low HO-1 levels allows HEME to accumulate; (4) high amounts of HEME favors the accumulation of the

Nihon University School of Dentistry, Tokyo, Japan gp91phox subunit which subseuqently increases NADPH oxidase activity; and (5) ultimately leads to $\mathrm{H} 2 \mathrm{O} 2$ accumulation. We hypothesize that by increasing $\mathrm{HO}-1$, as previously reported, HIV-1 infection was ameliorated ascribable to a reversal in Tat activity.

\section{Conclusion}

HIV-1 Tat lowers HO-1 activity which consequentially leads to $\mathrm{H} 2 \mathrm{O} 2$ accumulation. We suspect, based on a previous report, that increasing HO-1 ameliorated HIV-1 infection by reversing Tat activity.

Published: 13 September 2012

doi:10.1186/1742-4690-9-S2-P221

Cite this article as: Cueno et al: Heme oxygenase-1 reverses HIV-1 Tat activity: prospects for AIDS prevention. Retrovirology 2012 9(Suppl 2): P221.
Submit your next manuscript to BioMed Central and take full advantage of:

- Convenient online submission

- Thorough peer review

- No space constraints or color figure charges

- Immediate publication on acceptance

- Inclusion in PubMed, CAS, Scopus and Google Scholar

- Research which is freely available for redistribution
() Biomed Central

(c) 2012 Cueno et al; licensee BioMed Central Ltd. This is an Open Access article distributed under the terms of the Creative Commons :-1 Med Central Attribution License (http://creativecommons.org/licenses/by/2.0), which permits unrestricted use, distribution, and reproduction in any medium, provided the original work is properly cited. 